published works without attribution in his thesis. The report sparked an intense reaction hard to imagine in countries such as the United States and Britain, where the academic achievements (if any) or failures of politicians are not considered serious issues.

German citizens looked to the Internet to discover the extent of Guttenberg's plagiarism, which turned out to be quite shameless. The University of Bayreuth withdrew his $\mathrm{PhD}$ and is now investigating whether he had just been careless or had intended to deceive. At first, Guttenberg attempted to underplay the importance of "inadequate footnotes" in a thesis; the issue faded to insignificance, he implied, next to his momentous political mission of reorganizing the German armed forces and controlling their presence in Afghanistan. His popularity among the general public remained undiminished, and Chancellor Angela Merkel, herself a PhD physicist, tried to limit damage to her government by saying that she had "hired a politician, not a scientific assistant". That was a fatal mistake. Within days, tens of thousands of $\mathrm{PhD}$ holders had signed a letter deploring her "mockery" of an academic system that represented decency, honour and responsibility — attributes that they insisted should be reflected in a democratic government. Crushed by this attack of righteousness, Guttenberg finally resigned.

Like Guttenberg, Gelmini was a graduate in law. And like him, she felt that her driving ambition justified taking short cuts in academic procedures to get the degree that would help her political career. In 2001 she travelled from her home town of Brescia in the north of Italy to Reggio Calabria, in the far south, to sit her bar exams. At the time, pass rates in the north were below $10 \%$, compared with a rate of suspiciously more than $90 \%$ in Reggio Calabria, a city otherwise known for low academic standards. After the press revealed the Reggio Calabria bar exam to be a scam, the Italian academic community called for
Gelmini's resignation - to no avail. The irony of having a minister with responsibility for universities who herself cheerfully admits to having dodged academic rules is not lost on the community.

In Germany, Italy and neighbouring countries in Europe, politicians are frequently drawn from academia. Credentials help political careers,
"It is surprising and gratifying tofind that rage against an academic cheat can provole serious consequences." and nearly $20 \%$ of the German parliament hold PhDs. But then, almost 9\% of Italian parliamentarians are university professors, so the differing reactions to calls for resignation prompted by scholastic misdemeanours cannot be down to ignorance about how universities work. Instead, the difference seems to be based on how large a threat each government considers the weapon of moral correctness to be - and how dangerous is the academic community wielding that weapon.

Should anyone really have expected the government of Silvio Berlusconi to fear such a weapon?

It is more surprising, and gratifying, to find that in Germany, one of the world's richest and most powerful countries, rage against an academic cheat can provoke serious consequences. Not only was Guttenberg popular, but he hadn't previously made any serious political errors that would have seen charges of plagiarism considered the last straw.

Still, there may not be a lesson for many other countries here. Germany is known as the 'country of poets and philosophers' - a rare societal background, and one apparently conducive to propagation of honourable academic values. Like our more fortunate mutant mouse, all there seems plump and healthy, even as it remains unfathomably mysterious to those on the outside.

\section{Over the limit}

\section{Evidence should be considered when setting policy, but not to the exclusion of other factors.}

\section{$\mathrm{T}$} The evidence is clear. Statistics from the United States, Europe, Asia and Africa all point in the same direction: male drivers are more likely to crash their cars than females. Aggressive behaviour, rule-breaking tendencies and a greater willingness to take risks are all thought to contribute. Taken together, male drivers are a riskier bet, and face higher premiums for car insurance as a result.

Last week, the Court of Justice of the European Communities took a wrecking ball to this seemingly evidence-based policy. From December next year, insurance companies will no longer be able to discriminate on the basis of sex: men should see their premiums fall and women will pay more. The decision was greeted with howls of outrage in some quarters. From newspaper headlines declaring it to be "madness" to radio phone-ins that bemoaned a "lack of common sense", the underlying message from critics was that discrimination against men by insurance companies was fair because it was based on evidence.

The court's decision affects more than car insurance - life assurance premiums paid by men could rise to match those paid by women, where previously they were discounted because men on average die earlier.

Nature is a vocal and staunch supporter of evidence-based policymaking. Yet it is important to distinguish between policies that ignore the evidence and those that consider it but do not give it the deciding vote. Although the European ruling flies in the face of available research on accident and death rates, policy-makers have to consider other relevant factors as well as the scientific data. Europe introduced a laudable law in 2004 to ensure equality between men and women in access to and provision of goods and services. (Last week's ruling was prompted by a challenge under human-rights legislation to a get-out clause in the

2004 law for the insurance industry.) In this case, the drive in Europe to reverse practices that survive as a legacy of centuries of inequality and discrimination against women is right to trump the cold logic of the statistics. Besides, it is far from clear how insurance firms translate the sex differences to quantitative hikes in premiums for young men. The best evidence-based decision-making is also transparent.

Science, and so the data and evidence it gathers, serves society best when it is viewed as part of a wider assessment of risk - not an allpowerful framework within which policy must be placed. A report last week from the UK select committee on science and technology complained that the British government had dropped disruption to air travel by natural disasters from its national risk assessments in 2009, yet saw the eruption of Eyjafjallajökull in Iceland in April 2010 close airports, cancel flights and strand thousands of passengers around the world. The Geological Society in London told the committee that Earth scientists had warned the government of the potential for major disruption for a number of years, but felt that the policy-makers had ignored them. Or perhaps, the policy-makers had heard the warnings, weighed up the costs and benefits, but decided the risk was small enough to do nothing except cross their fingers. It is the job of scientists to raise such concerns, but it is the job of politicians to decide when to ignore them. Although the decisions may be judged with hindsight as being poor policy, they remain evidence-based. Politicians too, however, should not shy away from revealing their reasons.

Overstating the role that scientific evidence should have is most inappropriate when the stakes are highest. For global warming, for instance, the evidence is as clear as the statistical difference between male and female drivers. Yet the policy response must also take into account social, economic and political factors. It is legitimate, if short-sighted, to acknowledge that man-made global warming is real but argue that

$\rightarrow$ NATURE.COM To comment online, click on Editorials at: go.nature.com/xhunqv policies to cut emissions are too expensive to pursue. Dismissing those who take such a position as climate sceptics alongside those who deny the evidence is wrong. When setting policies, there are limits to the role that evidence can have. 